\title{
HEALTH ISSUES AND IMMIGRATION ON ELLIS ISLAND: THE CASE OF CARMELA SATURNINO
}

\author{
Eric Martone \\ Mercy College
}

If you had been an immigrant at Ellis Island during 1892 to 1924, what would you have done if you had been granted clearance to enter America while your daughter had not? Such was the situation faced by Carmela Caruso, whose daughter, Carmela Saturnino, had been barred admittance to America on the grounds that the young girl had a "loathsome and contagious disease." Through a document-based activity that uses a variety of documents, including photographs, students can explore the true case of Carmela Saturnino to learn about immigration on Ellis Island, connecting this case study to broader themes and issues in United States history and society. 'This activity will help students to develop their skills analyzing primary source documents, interpreting written information, making inferences, and drawing conclusions. ${ }^{2}$

A special feature of this primary source activity is its focus on a single teenage girl. Since I have always been of the opinion that people of the past are essentially the same as the people of the present, I thought that if students examined the history of a girl roughly their own age to explore issues in United States history, it would rouse in them a greater degree of connection and empathy for the past. ${ }^{3}$ The perception that it is easier for students to imagine a situation from the point of view of someone else their own age, thereby enabling them to better relate with "characters" in a historical drama, is not new in itself. Historical trade fiction, which is a popular way to incorporate social studies at the elementary level, often presents tales of the past from the point of

\footnotetext{
${ }^{1}$ The documents used in this activity, most of which have never been published before, were collected during my participation in "Ellis Island and Immigration to America, 1892-1924," a National Endowment for the Humanities Landmarks of American History Workshop for Teachers, run by Save Ellis Island in 2007. The full text for the first document, the 1891 Immigration Act, can be found at: http://library.uwb.edu/guides/USimmigration/1891_immigration_act.html. The documents relating to Carmela Saturnino and other immigrants treated at the Ellis Island immigrant hospital can be found in the Records of the Public Health Service, General Immigration Files, and the General Records of the Department of Labor at the National Archives.
}

${ }^{2}$ Lisa Hutton, Tim Keirn, and Dave Neumann, "The State of K-12 History Teaching: Challenges to Innovation," Perspectives on History, $50: 5$ (2012), 25; Chauncey Monte-Sano, "Beyond Reading Comprehension and Summary: Learning to Read and Write in History by Focusing on Evidence, Perspective, and Interpretation," Curriculum Inquiry, 41 (2011), 212-248.

${ }^{3}$ Elizabeth Yeager, Stuart Foster, Sean Maley, Tom Anderson, and James Morris, "Why People in the Past Acted as They Did: An Exploratory Study in Historical Empathy," International Journal in Social Education, 13 (1998), 8-14; Peter Lee and Rosalyn Ashby, "Empathy, Perspective Taking and Rational Understanding," in Historical Empathy and Perspective Taking in the Social Studies, eds., O.L. Davis, Elizabeth Yeager, and Stuart Foster (Lanham, MD: Rowman and Littlefield, 2001), 199-222. 
view of a child or adolescent protagonist. ${ }^{4}$ I therefore sought to incorporate one of the elements of historical trade fiction that makes the genre engaging to younger students to the teaching of history at the secondary level. ${ }^{5}$ To further this approach, I intentionally grouped the primary sources I collected into three sections and tried to end each section with a "cliff-hanger" to pique students' interest. The questions at the end of each group of primary sources help students interpret the documents within the provided historical context as well as to recreate "episodes" in the unfolding historical drama of our teenage subject. To accomplish this task, students are exposed to and gain practice in the historical method. As a result, this primary source activity not only helps students learn to think "historically," but seeks to make this cognitive process more engaging by building on some of the familiar components of historical fiction to remove several of their common misconceptions about historical knowledge. Students should see more clearly how "the leap from analyzing evidence to constructing interpretive accounts" is made. ${ }^{6}$

Following the conventions of the standard Document-Based Question format of the AP College Board, this activity labels the primary sources as a series of "documents." The content of the documents in this activity is not particularly difficult to grasp. However, many of the documents are written in "legalese" that can intimidate some students. The documents also use many words with which some students are unfamiliar. I have found this to be the case especially with students with lower reading levels and ESL students. Consequently, some secondary students might have difficulty with this assignment. Advanced middle school students, however, might be able to use this activity too. And it certainly could work at the college level.

\footnotetext{
${ }^{4}$ Examples include Scholastic's "The Life and Times" book series, which uses the lives of fictional adolescents to explore the past. Two entries in the series that I have used in my classes are Barry Denenberg, Atticus of Rome, 30 B.C. (New York: Scholastic Inc., 2004), and Barry Denenberg, Pandora of Athens, 399 B.C. (New York: Scholastic Inc., 2004). Another example, which explores the French resistance movement during World War II through a fictionalized account of the life of an actual teenage spy, is Kimberly Brubaker Bradley, For Freedom: The Story of a French Spy (New York: Laurel Leaf Books, 2003). On elementary social studies, see Walter C. Parker, Social Studies in Elementary Education, 14 ${ }^{\text {th }}$ ed. (Boston: Pearson, 2012), 385-392.
}

\footnotetext{
${ }^{5}$ A book taking a similar teaching approach is Richard M. Wyman, Jr., America's History Through Young Voices: Using Primary Sources in the K-12 Social Studies Classroom (Boston: Pearson, 2005).

${ }^{6}$ Some of these common misconceptions include the notion that historical narratives are "true or objective accounts of the past, with little or no room for ambiguity or contestation" and the belief that history is "an objective recording of the past, assembled from a clear and complete body of information" rather than "interpretive reconstructions of the past, assembled from fragmentary, sometimes contradictory traces." See Terrie Epstein, "Preparing History Teachers to Develop Young People's Historical Thinking," Perspectives on History, $50: 5$ (2012), 36.
} 


\section{Learning Objectives}

Upon completion of this lesson, students should be able to

-Explain some of the reasons behind U.S. immigration policy in the early twentieth century;

-List some of the effects U.S. immigration policy had on potential immigrants;

-Use inference to draw conclusions about some of the effects U.S. immigration policy had on the United States;

-Develop their abilities to read, analyze, and interpret primary source documents;

-Draw conclusions and inferences from primary source documents.

\section{NCSS Curriculum Themes}

I. Culture

II. Time, Continuity and Change

III. People, Places and Environment

V. Individuals, Groups and Institutions

VI. Power, Authority and Governance

$\mathrm{X}$. Civic Ideals and Practices

\section{Preparing to Teach this Lesson}

This document-based activity should be used within a larger unit on immigration in the United States during the late nineteenth and early twentieth centuries to complement the unit and further develop students' ability to read and analyze primary source documents. You should make copies of the document activity sheets (located at the end of this article) for each student. These document activity sheets, ready for classroom use, contain the background information necessary for the students to draw conclusions and interpretations from the documents, the documents themselves, and a series of questions to guide the students in reading and analyzing the documents.

You might also wish to incorporate the Ellis Island website (http://www.ellisisland.org/) into the lesson, before or during the suggested activity. Using the website's passenger search feature, you or the students can look up the ship manifest record for Carmela Saturnino (she is listed as Carmela Saturnini). There is some doubt about whether her last name was "Saturnino" or "Saturnini"-U.S. official documents arbitrarily use both spellings. She lived in Benevento, Italy, departed from Naples, and arrived at Ellis Island with her mother and siblings on December 16, 1916, aboard the Giuseppe Verdi. Both a copy of the original ship manifest and a photograph of the Giuseppe Verde are available through the passenger search. If you decide to use the ship manifest, it is important to note that while Saturnino's siblings are identified as 
Michele (10 years old), Donato ( 7 years old), and Eva ( 3 years old), in the manifest in other documents, Michele is referred to as Michelina.

\section{Suggested Activity}

There are several different ways in which the activity can be carried out in the classroom. At least one full class period is needed in order for the students to carry out the primary source document activity, which includes reading background information and documents included as part of the document activity sheets, and develop interpretations. Students should read the background information first, either as homework or in the classroom-aloud or silently (or both) prior to reading the documents. You might ask some general questions to determine whether students understood the background material. The next step involves reading the documents, which again can be read either aloud or silently (or both).

After reading the documents, students should go through the questions located throughout the document activity sheets. These questions can be answered individually by each student or as part of a group discussion. Another possibility is to divide the students into groups and have each group answer the activity sheet questions. Each group's answers could be compared with those of the other groups in a classroom discussion. The use of a guiding question to orient students in connecting the documents to the broader issue is also useful. One suggestion for a guiding question: "What were the U.S. immigration policy's health restrictions during the early twentieth century and what effect did these have on entering immigrants?"

\section{Assessment}

A variety of methods can be used to determine what students have learned from the document-based activity. In addition to informal assessments conducted through your observations and from student participation and responses, you could collect students' answer to the questions located throughout the activity sheets. Another possibility is to follow up the students' answers/discussion with an essay answering the lesson's guiding question: "What were the U.S. immigration policy's health restrictions during the early twentieth century and what effect did these have on entering immigrants?" Another possibility is for students to write a petition from an immigrant to be admitted through Ellis Island or write a letter of refusal from the point of view of an immigration officer. In each instance, the letters should reflect the point of view of the author of the letter and should provide reasons why the immigrant should or should not be admitted into the U.S., drawn from the documents studied. Finally, students could write a piece of historical fiction about Carmela Saturnino's experiences using both the documents and what they learned in the suggested activity. 


\section{Extending the Lesson}

To extend the lesson, you might have students look at additional documents based on health issues and immigration policy from this period to demonstrate to students that the case of Carmela Saturnino was not an isolated incident, but rather one example of a broader issue. Another extension activity is to explore what actually happened to immigrants whose admittance to the U.S. was rejected. Shipping companies were held responsible eventually for the return voyage of the rejected immigrants who secured passage on their vessels. A lesson could be constructed using the following questions: What consequences do you think this policy had on shipping companies' willingness to bring potential immigrants to the U.S.? In effect, who became responsible for "inspecting" immigrants? Are there any similarities today?

\section{Conclusion}

During my eight years as a high school teacher, this was one of the most effective primary source activities I ever used. I taught this activity to three classes per year for four years. Each time, my students responded well to the focus on one teenager's ordeal and enjoyed piecing together her story from documentary fragments. I taught in an urban school district in the Northeast, where roughly $1 / 3$ of my students had ancestors who passed through Ellis Island, which was also within field trip distance. For another $1 / 3$ of students, however, the immigration experience was much more immediate. I consequently incorporated activities within my unit on early nineteenth- and twentiethcentury immigration that connected past immigration to the present, using contemporary examples to enhance historical understanding. While students might proclaim a preference for learning about the present, contemporary examples alone do not help students develop historical (or long-term) thinking skills; they must be used in conjunction with activities like this one.

********

\section{Health Issues and Immigration on Ellis Island: The Case of Carmela Saturnino}

Name

Background Information: On December 16, 1916, Carmela Saturnino arrived at Ellis Island with her mother Carmela Caruso (married Italian women kept their maiden names) and siblings aboard the Giuseppe Verdi. They, like many other immigrants, left their homeland to seek new lives in America. Between 1892 and 1954, twelve million immigrants entered the United States through the federal government's processing center on Ellis Island, most between 1892 and 1924. This unprecedented influx, part 
of the largest mass migration in American history at the time, is matched only by what some demographers and historians say is a comparable wave of immigration today.

Then, like now, the federal government had the responsibility for managing the numbers of people entering the country, while at the same time keeping America's "golden door" opened for those who met the requirements. Legislation enacted in 1891 established the Bureau of Immigration within the Treasury Department, and stipulated the reasons for which immigrants could be denied admission. Once in place, this process facilitated further restrictive legislation in 1903 (excluding beggars, the insane, prostitutes, and anarchists), 1907 (excluding the feebleminded, imbeciles, persons with physical or mental defects that might affect their ability to work, etc.), 1917 (adding a literacy requirement), and 1924 (establishing a quota system). The legislation led to federal guidelines that mandated health inspections of each arriving immigrant, with the implicit goal of building a healthy, robust workforce for America's growing industrial economy, and controlling the numbers of people who, because of health or disability, would become "public charges." Ill or infirm immigrants received treatment upon arrival. Of the twelve million immigrants who passed through Ellis Island, 1.2 million spent some time in the Ellis Island hospitals, either for further evaluation or for treatment, and 1.2 million were detained for other reasons. Of these 2.4 million, only a total of 250,000 were returned to their country of origin and denied entry.

\section{Document 1: Fifty-First Congress, Sess. II, Ch. 551, 26 Stat. 1084, 1891}

"That the following ... aliens shall be excluded from admission into the United States ... All idiots, insane persons, paupers or persons likely to become a public charge, persons suffering from a loathsome or a dangerous contagious disease, persons who have committed a felony or other infamous crime ... polygamists, and also any persons whose ticket or passage is paid for with the money of another or is assisted by others to come ... All decisions made by the inspection officers or their assistants touching the rights of any alien to land, when adverse to such a right, shall be final unless appeal be taken to the superintendent of immigration, whose action shall be subject to review by the Secretary of the Treasury."

Document 2: To Frederic Howe, U.S. Commissioner of Immigration, Ellis Island, December 26, 1916 (National Archives)

"The undersigned immigrant - Caruso, Carmela - hereby respectfully appeals from the decision of the Board of Special Inquiry excluding herself and her children Saturnino, Michelina-Donato- and Eva- from landing in the United States ... the children as aliens likely to become public charges ... Your petitioner arrived here with another daughter Saturnino, Carmela aged 15-certified as having Tinea Tonsuras (sic)-ringworm of the scalp. The exclusion of said daughter has been the main reason for the exclusion of the entire family ... Your petitioner is coming here to reach the residence of her husband ... and he has resolved to establish his residence ... [in America] and sent for his family. Your petitioner has sold every thing in Italy and the deportation of the entire 
family would be a great hardship for them. Consequently, she respectfully prays you to permit the landing of the family and to grant that the certified daughter be cured at Ellis Island ... at the husband's expense."

Document 3: Medical Certificate, Public Health Service, Ellis Island, December 28, 1916 (National Archives)

"Alien Carmela Saturnini (sic), aged 15 years, native Italy ... December 16, 1916, certified 'Tinea Tonsurans (ringworm of the scalp) a loathsome and contagious disease.' The disorder ... is not easily curable and alien cannot be landed without danger to other persons. Owing to the chronicity of this disease and its proneness to relapse it is impossible to state ... the length of time ... required to effect a cure."

\section{Questions to ask:}

-Why was the United States concerned about immigrants who were likely to become "public charges"? How does this view reveal the U.S. government's attitude toward immigration and the role of immigrants in American society?

-Why was Carmela Saturnino barred from entry into the U.S.? Do you think that this reason was justified? Why or why not?

-Why do you think Carmela Caruso and her other children (Michelina, Donato, Eva) also were barred from entering the U.S.? Do you think that this reason was justified? Why or why not?

Document 4: Intent of Payment for Medical Services submitted on Behalf of Carmela Saturnino, January 1917 (National Archives)

"Vincenzo Saturnini (sic) and Savine Tesone ... and Jim Marinelli ... are held firmly bound unto the People of the United States ... in the sum of Five hundred ... dollars, liquidated damages ... Whereas the alien, Carmela Saturnini (sic) ... has been excluded from entering the United States because afflicted with a ... loathsome contagious disease ... has applied to the Secretary of Labor for permission to remain in this country for treatment ... and whereas the Secretary of Labor has granted permission to said alien to land temporarily for medical treatment in the Ellis Island Immigrant Hospital ... Now, therefore, the conditions of this obligation are such that ... the relatives or other interested persons shall ... have deposited with the Commissioner of Immigration a sum ... sufficient to cover the cost ... of treatment for sixty days and at least fifteen prior to the expiration of aid period make a further deposit to cover [further] cost of treatment [and repeat this procedure] ... until the alien is cured and permanently landed or ... otherwise disposed of [including deportation]."

Document 5: Below is a photograph of immigrant children who arrived in America with favus, a skin disease of the scalp, and were treated in the hospitals on Ellis Island (image from Save Ellis Island, http://www.saveellisisland.org). 


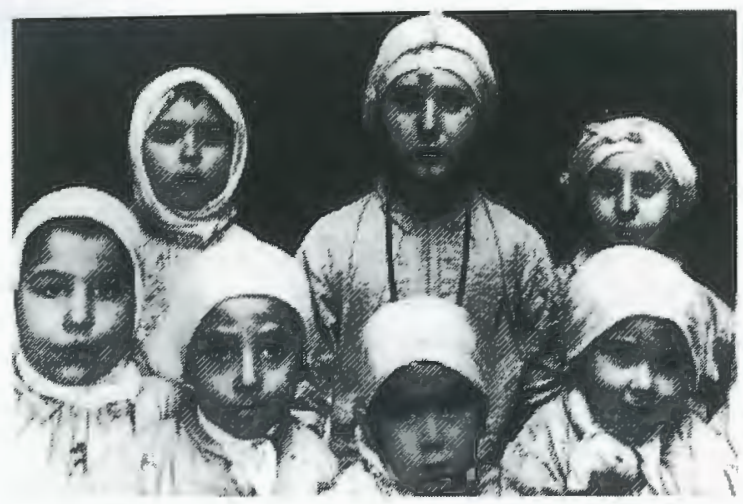

\section{Questions to ask:}

-Why do you think the U.S. government approved Carmela Caruso's appeal on behalf of her daughter?

-What did the U.S. government require in order to consider Carmela's family's request to allow her entry into the U.S.? Why do you think this requirement was made in this case and/or for all immigrants?

- Are there any clues to determine whether or not Carmela's father could easily afford his daughter's medical expenses at Ellis Island? Explain.

Document 6: Letter to Commissioner-General of Immigration, from U.S. Dept. Of Labor, Immigration Service, January 9, 1917 (National Archives)

"In accordance with Department decision No. 54188755 of Jan. 3, 1917 the alien Caruso, Carmela and children, Michelina, Donato, and Eva were duly admitted Jan. 9, 1917."

Document 7: Letter to the Commissioner-General of Immigration, Washington, DC, from the Asst. Commissioner, U.S. Department of Labor, Immigration Service, June 7, 1917 (National Archives)

"I have to advise you that on June 2 nd a medical certificate was issued to the effect that Carmela Saturnino was no longer suffering from a loathsome contagious disease. She was taken before the Board of Special Inquiry and admitted."

\section{Questions to ask:}

-When were the Saturninos granted entry into the U.S.?

- How long was Carmela quarantined, and what happened to her when her treatment was finished?

- What do you think would have happened to Carmela and/or the Saturnino family if Carmela had not been cured? 